\title{
STAKEHOLDERS' PERSPECTIVES TOWARD A COMMUNITY-BASED RURAL TOURISM DEVELOPMENT
}

\author{
Kalsom Kayat ${ }^{\mathrm{a}}{ }^{*}$ \\ ${ }^{a}$ College of Arts and Sciences, Universiti Utara Malaysia, 06010 Sintok, Kedah, \\ Malaysia, e-mail: kals932@uum.edu.my \\ ${ }^{*}$ Corresponding author
}

\begin{abstract}
A study guided by stakeholder, social exchange and power theories was carried out to investigate the level of stakeholders' interests in and their concerns towards Kampung Pelegong Homestay (KPH) Programme. Using a case study approach, the study examines the views of stakeholders in 2005 on the development of KPH Programme and explores the extent to which the conception of stakeholder and the notion of social exchange and power theory provide a satisfactory understanding of a specific case of stakeholder analysis. The study finds that the stakeholders' interest in the development of the homestay may be explained by any and the combination of the three components: their power, or their lack of power, to affect the program, their dependency on the program, and the stakes they have on the development. The stakeholders will have interests in the programme development when they are affected by the programme or when they have the ability to affect the programme.
\end{abstract}

Keywords: Stakeholder theory, social exchange theory, tourism development, rural tourism

\section{Introduction}

Rural tourism is currently one of the emerging tourism products in Malaysia. Rural tourism has existed for a long time in Malaysia but it has only recently received recognition as a tourism product with the preparation of its rural tourism master plan in 2001. A market survey indicated that foreign tourists who came to Malaysia spent $15 \%$ of their overnights in rural areas. In addition, the study also found that market profile of foreign visitors to rural Malaysia is balanced, with Britain, Northern Europe, Australia/New Zealand and the United States each representing valuable source market (United Nation Development Programme, 2003). Challenges faced by rural tourism in Malaysia include lack of good quality accommodation and other tourism facilities in the rural areas, problem with litter and untidiness, and the general "information deficit" regarding the rural tourism attractions in Malaysia.

One specific form of rural tourism promoted by the Malaysian government is the homestay programme organized by communities in rural areas throughout the country. 
Under this programme, visitors have the opportunity to visit rural villages and attractions and to experience the hosts' culture while the hosts have the opportunities to be a part of the tourism product and to receive the socio-economic benefits from it (Ministry of Culture, Arts and Tourism 2001). The profile of homestay visitors is very different from that of mainstream visitors to rural Malaysia. Currently, the homestay programs throughout Malaysia rely on the Japanese student market (Kayat 2007). The recent announcement by the Government that it intends to expand the homestay programme throughout the country indicates the potential of growth for this specific tourism sector, which has already seen an increase of operators from over 800 in 2003 to 2,746 in 2008 (Sittamparam, 2008).

Rural tourism can be viewed as a sustainable alternative to mass tourism, as it can do more in terms of 'conserving for the future' and 'benefiting the present' (Lewis, 1998). This study recognizes the importance of exploring the views held by different parties towards the development of a rural tourism destination in Malaysia as support from different parties whose lives depend on the rural areas is crucial for the sustainability of the development. To have the best probability for success and sustainability, rural tourism must fulfil several conditions. Among them are that it must get the support and participation of the local government and the community, and there must be coordination and cooperation between business persons and local leadership (McGehee and Andereck, 2004).

To involve stakeholders, researchers and planners must first identify and appreciate the stakeholders' elements of interests and concerns thereby allowing the planners to take into account the specific interest areas in the planning, development, and management processes. Bramwell and Sharman (1999) proposed a number of likely stakeholder groups and their different interests that can influence the framing of the tourism product:

$\checkmark$ Those with community interests (such as churches or other non-profit organizations);

$\checkmark$ Those with special interests (disabled individuals, senior citizen groups);

$\checkmark$ Those with environmental concern;

$\checkmark$ Local government members and councils

$\checkmark$ Those with recreational interests;

$\checkmark$ Those with economic interests;

$\checkmark$ Those with developmental concerns;

$\checkmark$ Other individual local residents.

To date, no studies have been undertaken to explore the views of respective stakeholders on rural tourism development in Malaysia. Studies are needed to identify specific challenges of rural tourism development in Malaysia and the stakeholder approach is indeed a viable alternative to carry out these investigations. This study aims to examine the interests and concerns of stakeholders in 2005 on the development 
of a rural tourism product in Negeri Sembilan, namely its Kampung Pelegong Homestay (KPH) Programme. The conception of stakeholder and the notion of social exchange and power theory, which is discussed in the following section, are chosen as the overall guide for the study. Specific objectives of this research are to gain insights into and to use a stakeholder approach to investigate:

1. The stakes and power of different stakeholders in the development of Kampung Pelegong as a homestay programme.

2. The level of stakeholders' interests in the Programme and their opinions (challenges and concerns) towards Kampung Pelegong Homestay Programme.

3. The extent that stake and power influence stakeholders interests.

The results from the study will produce necessary knowledge to effectively plan for and manage homestay programs as rural tourism products for Malaysia. In addition, the study could also contribute to the understanding of the stakeholder concept in the tourism field.

Kampung Pelegong, a village in Negeri Sembilan, Malaysia is located $15 \mathrm{~km}$ from the capital city of Seremban and $30 \mathrm{~km}$ from the Kuala Lumpur International Airport. The ancestors of most of the villagers were immigrants from West Sumatran who settled in Negeri Sembilan. They brought along their Minangkabau culture that was passed to the present generation. As Negeri Sembilan is the only state in Malaysia that practices Minangkabau customs and culture, the state government is keen to turn it as an important tourism product by developing several of its communities into cultural tourism destinations. Kampung Pelegong is one of the communities chosen for that purpose. It has received important awards from different government agencies including Best Village in the State Award in 2001 and second place for Best Natural Resort category in the Tourism Malaysia competition held the following year.

The community in Kampung Pelegong has always been active in community projects. When the government began to develop rural tourism, specifically through homestay programs in the rural area, the community of Kampung Pelegong established its own homestay programme in August, 1996. They received their first international guests, consisting of 30 international students, in 1997 through an exchange programme organized by the Youth Council of Negeri Sembilan.

Starting with only two households as homestay hosts, there are to date 25 households that are certified as homestay hosts. The homestay programme hosted 500 guests annually between 1997 and 2002, and the number increased to 900 guests in 2003 and to 1633 guests in 2004 (Fatimah, 2005). Due to its strong potential as a cultural tourism attraction, Kampung Pelegong was also chosen by the government to become the Pilot Model Area for detailed planning purpose in the national rural tourism master plan study that took place in between 2000 and 2001. It has received continuous domestic and international tourists packaged or organized by travel agencies, the Malaysian Homestay Association, and government agencies, allowing it 
to be a suitable living case for examining stakeholders' concerns in the development of a cultural rural tourism product.

\section{Literature Review}

Understanding stakeholders in rural tourism development

Studies have shown that rural tourism in a community can do more in terms of 'conserving for the future' and 'benefiting the present' if it is supported by its residents and if the community keeps control and ownership of, and participate in its offering (Lewis, 1998). Community-based cultural rural tourism such as the homestay programme should be able to bring immediate benefits to both the visitors and hosts. A case study of a French Acadian region on an island in eastern Canada undertaken by MacDonald and Jolliffe (2003) supported this hypothesis and revealed that cultural rural tourism in that region provides a potential short and long-term economic benefit for rural communities (the suppliers) and that cultural tourism provides education, entertainment, and enrichment for tourists (the customers).

To have the best chance for success and sustainability, rural tourism must fulfill several conditions, one of which is that it must get support and participation from the local government and the community, and there must be coordination and cooperation between business persons and local leadership (McGehee and Andereck, 2004). Local government, local leadership, business persons and the community within a rural tourism context are widely known as 'stakeholders' for that particular rural tourism product. Stakeholders' involvement is a critical part of sustainable tourism development.

Many earlier writers believe that tourism development, especially the type of tourism development viewed as the more 'responsible' kinds such as rural tourism, must consider inputs, collaboration and cooperation among related stakeholders (see for example Ritchie, 1993; Jamal and Getz, 1997; and Hall and Lew, 1998). Increasing emphasis is being placed on tourism planning that it take into consideration these interests and concerns so that they may collaborate to develop a shared 'vision' for tourism (Jamal and Getz, 1997; Ritchie, 1993). With this knowledge, tourism planners and developers can better address the concerns of the local community and plan developments that represent the interests of the residents, business owners, government officials and other stakeholder groups.

\section{Stakeholder, power and social exchange theories}

A stakeholder is "any group or individual who can affect, or is affected by, the achievement of a corporation's purpose” (Freeman, 1984: vi). Stakeholder theory stresses the importance of examining individual interests and to satisfy as many of those interests as possible with the understanding that stakeholders have particular relationships with the firm, it is critical for the firm to nurture this relationship 
(Freeman, 1984). This theory may also be used to explain the relationship between a stakeholder in a development and the development authority and, as any kind of development consists of social exchanges between the stakeholders and the party responsible of the development, this explanation may be supported by the power and social exchange theories.

These social exchanges include, "any voluntary activity between two organizations which has consequences, actual or anticipated, for the realization of their respective goals or objectives" (Levine and White, 1961:588). These exchanges may be motivated by each party's interests and stakes, which are what a stakeholder will lose if the project does not do well, and what it will gain if it does. Besides its interests and stakes, the exchange party's (or the stakeholder's) degree of dependency may also be useful to explain its concern with the development. For example, on Langkawi, residents who are economically dependent on the tourism industry have different concerns than those who are less economically dependent on it (Kayat, 2000). The degree of dependency, on the other hand, is somewhat dictated by their power.

Power influences the exchange between the production entity and the stakeholders (Savage et al., 1991; Burton and Dunn, 1996). The present author observes that in many cases, power is influenced by the resources owned by the stakeholders. Stakeholders' power differ according to the resources they have; there are stakeholders with much power (resources that are much needed in development) and those with little power (resources that are less needed in development) (Healy, 1998). Groups or individuals who have no resources to exchange have little power and can be considered not important because rationally, people enter into exchanges if they feel they can gain from the exchange. These are relationships where a party provides resources to others based on the expectation that the exchange will be reciprocated (Axelrod, 1984; Burton and Dunn, 1996). Power also may explain the dependency of each party in the exchange. In the case of the homestay programme, the stakeholders' concern may be explained by the nature of their relationship with the party responsible for its development, which in turn, is influenced by their interest, stakes, power, and dependency.

In addition, feelings of care or concern may also facilitate an exchange, based more on moral and less material grounds. Parties involved in this kind of exchanges gain internal satisfaction. A caring entity will also usually be a powerful entity with resources that is willing to share resources with the cared-for as part of its attempt to satisfy the needs of the cared for and the needs to be a complete person (Burton and Dunn, 1996).

Stakeholder approach has been used in tourism studies, particular as it relates to their perceptions towards tourism impacts and development strategies. For example Yuksel et al. (1999) interviewed stakeholders on tourism issues and changes caused by tourism at Pammukale, Turkey. The study focused on common views, which were 
often found to link stakeholder groups. In another study, Easterling (2005) examined the stakes of different resident groups based on their types of residency and explored their perceptions and attitudes toward tourism development. Additionally, there are several studies on tourism impacts that did not focus on stakeholder approach per se, yet produced findings that support the present study's notion of the important utility of stakeholder and social exchange theory in explaining people's perceptions and attitudes towards tourism. Variables that expound stakeholder and social exchange theory in explaining differences in residents perceptions toward tourism development include economic dependency (examples are studies by Murphy, 1981; Tyrrell and Spaulding, 1984; Pizam and Pokela, 1985; Lankford, 1994; Haralambopoulos and Pizam, 1996), resident involvement in tourism decision making (Goudy, 1977; Ayers and Potter, 1989), and level of knowledge about tourism and the local economy (Milman and Pizam, 1988; Lankford, 1994). For example, Lankford (1994) examined the attitudes of four groups of stakeholders: business owners, paid government officials, elected/appointed officials, and residents of the Columbia River Gorge region of Oregon and Washington. Yet, stakeholder theory or approach is never mentioned by Lankford in his study although the present author believes that these theories could explain Lankford's findings. The present study attempts to apply both theories in its methodology and findings.

\section{Methodology}

A case study was undertaken for this study, which sought to analyze stakeholders' voices themselves, an approach which anthropologists have also used (Black, 1996). Knowledge in a case study is mainly developed by collecting interview data and subjecting the data to induction in order to fulfill the research objectives (Gall et al., 1996). The study begins with establishing a 'stakeholder map', following Robson and Robson (1996) whereby all groups with a 'stake' in the cultural rural tourism development in Kampung Pelegong were identified. The study focuses on the diversity of the stakeholder groups based on their interest, stakes, power, and dependency on the programme.

Key respondents from each of the stakeholder groups identified were chosen based on their involvement and interest in the homestay programme in Kampung Pelegong. The stakeholder groups, and the number of key informants for each, were: central and local government officials (2), Kampung Pelegong residents who are awarded the homestay operator certifications (9), Kampung Pelegong Homestay Programme Committee members (2), Kampung Pelegong residents who are not members of Kampung Pelegong Homestay Programme Committee (3), guests to Kampung Pelegong Homestay Programme (5), organizers that bring groups to Kampung Pelegong Homestay Programme that are not from the travel industry (2), and tour operators that are involved in selling Kampung Pelegong Homestay Programme (2). 
The selection of respondents for interview was by purposive sampling whereby respondents who where in the best position to provide information required were purposefully selected (Sekaran, 1992). This sampling technique, known as purposive sampling (Sekaran, 1992), was deemed appropriate as the category of people having the information that was sought for was limited within the time constraints of the study. What was significant for this study was the involvement of those individuals deemed relevant to the study purpose. At the beginning, several individuals within each group were asked to participate in the interviews and were asked to identify any other key informants that they knew of. This generated a total list of potential respondents. Attempts were made to contact each of these individuals via email and telephone. This resulted in 25 key informants above who agreed to participate in the in-depth, semi-structured interviews which were conducted face-to-face in Malay and/or English.

The interviews were conducted by the lead researcher and by fellow researchers (in pairs) using personal conversations. Initial interview questions followed those used in MacDonald and Jollife (2003) study which include respondents observation on the development and progress of tourism in the area, and their attitudes and perceptions of rural tourism development in Kampong Pelegong. As more knowledge was gained throughout the study period, questions became more focused on their interests and opinions regarding the homestay programme development, and the importance of KPH Programme development to their livelihoods at the personal, family or community level. Questions were open ended in order to gain more spontaneous opinions and to avoid the potential bias from restricting responses to the researcher's own fixed categories (Ryan, 1995). The interviews were, when conducted in a formal situation, tape-recorded or, when conducted during more informal or unplanned situations, written in the form of notes with reflection in field diaries. Transcriptions of the taperecorded interviews as well as the reflections were done immediately after the fieldwork.

Transcripts for each taped interview were checked for internal consistency and corroborated with other interviews. A qualified translator assisted in translating transcripts of conversations in Malay into English. Analysis of the interviews for meaning, salience and connections followed the 'framework' approach developed by Ritchie and Spencer (1995). At the core of this method is the use of the study proposition to categorize stakeholder responses. The research proposed three categories for the responses: 1) the importance of the homestay programme to the stakeholders; 2) their interests in the programme, and 3) the power they have that will influence their opinions (challenges and concerns) towards KPH. The fieldwork and analysis were conducted over a period of 12 months in 2005 and 2006 during which the research team stayed in Kampung Pelegong for a total of five times; one in a duration of a week and the other four times in a duration of two days each. 


\section{Study Findings}

Following Robson and Robson (1996), the study established a 'stakeholder map', whereby all groups with a 'stake' in the cultural rural tourism development in Kampung Pelegong were identified. The study established eight groups with a 'stake' in the cultural rural tourism development in Kampung Pelegong. During the interviews, the respondents were asked about the importance of KPH Programme development to their livelihoods at the personal, family or community level. Their responses were categorized and analyzed according to the 'stakes' that they may have in the programme. The findings (Table 1) indicate that there is a close match between the stakeholder group's hypothetical interests and examples of their expressed 'stake'.

Interesting outcome relating to the interests and stakes of two groups require further explanation. Respondents in the KPH certified operators group only mentioned their economic interests after the researcher asked them specifically whether or not the homestay programme contribute to their income. And the respondents from the organizer group were a bit hesitant to declare the cost of the homestay package and the price they charge each participant. Nevertheless, it was observed that these professionals had other alternatives to organize their training but KPH was chosen as their training location because it assists them in achieving their objectives effectively and efficiently. Furthermore, KPH is conveniently located close to Kuala Lumpur, the capital of Malaysia, and the homestay is equipped with training facilities such as the multipurpose hall, the open space for activities, the operators' homes and households for accommodation and meals, and again, the rural ambiance that are suitable for training.

Table 1 Respondents' interest and stakes in Kampong Pelegong Homestay Program

\begin{tabular}{|l|l|l|}
\hline Category & Interests & Expressed 'stakes' \\
\hline $\begin{array}{l}\text { Government } \\
\text { officials }\end{array}$ & $\begin{array}{l}\text { National } \\
\text { tourism } \\
\text { promotion } \\
\text { development } \\
\text { al concerns }\end{array}$ & $\begin{array}{l}\text { "Home stay programs...anything about home stay } \\
\text { is under me. I am the person in the Ministry that } \\
\text { takes care of the home stay..." } \\
\text { "Homestay is one of the tourism products in } \\
\text { Negeri Sembilan that the state is really keen to } \\
\text { promote. I think in Malaysia, homestay di Negeri } \\
\text { Sembilan sangat unique. I think that is our } \\
\text { strength and I am working to majukan the our } \\
\text { homestays". }\end{array}$ \\
\hline $\begin{array}{l}\text { KPH } \\
\text { Programme } \\
\text { members }\end{array}$ & $\begin{array}{l}\text { interest } \\
\text { "I have and have been involved with this homestay } \\
\text { from the very beginning. I want this homestay to } \\
\text { develop for my kampong people as well" } \\
\text { "The whole of Malaysia has heard about }\end{array}$ \\
\hline
\end{tabular}




\begin{tabular}{|c|c|c|}
\hline & & $\begin{array}{l}\text { Kampong Pelegong homestay, it is often in the } \\
\text { newspapers, I entered this association because I } \\
\text { believe in that homestay help to develop this } \\
\text { kampong." }\end{array}$ \\
\hline $\begin{array}{l}\text { KPH } \\
\text { Programme } \\
\text { hosts / } \\
\text { certified } \\
\text { operators }\end{array}$ & $\begin{array}{l}\text { Economic } \\
\text { interest }\end{array}$ & $\begin{array}{l}\text { "I entered the homestay programme because I like } \\
\text { people to visit the house; I like to receive the } \\
\text { tourists that come." } \\
\text { "These homestay can also bring income..." }\end{array}$ \\
\hline $\begin{array}{l}\text { Kampung } \\
\text { Pelegong } \\
\text { residents }\end{array}$ & $\begin{array}{l}\text { Community } \\
\text { interest }\end{array}$ & $\begin{array}{l}\text { "I did not enter this homestay programme, but it } \\
\text { has something to do with me...this is my place" } \\
\text { "Perhaps, this homestay has something to do with } \\
\text { my because my children always go and see those } \\
\text { tourists that come" }\end{array}$ \\
\hline $\begin{array}{l}\text { KPH } \\
\text { Programme } \\
\text { guests }\end{array}$ & $\begin{array}{l}\text { Recreational } \\
\text { interest }\end{array}$ & $\begin{array}{l}\text { "We were sent here by our lecturer. This is part of } \\
\text { our coursework, but we also feel like this is a } \\
\text { tourism experience" } \\
\text { "Our package is about cultural experience in the } \\
\text { rural area. We are here to enjoy the rural } \\
\text { atmosphere". }\end{array}$ \\
\hline Organizers & $\begin{array}{l}\text { Economic } \\
\text { interest }\end{array}$ & $\begin{array}{l}\text { "This is a perfect setting to instill confidence and } \\
\text { to motivate my participants...of course; the cost of } \\
\text { the package is attractive". } \\
\text { "We are in the consulting business; one of our } \\
\text { products is motivational training..." }\end{array}$ \\
\hline $\begin{array}{l}\text { Tour } \\
\text { operators }\end{array}$ & $\begin{array}{l}\text { Economic } \\
\text { interest }\end{array}$ & $\begin{array}{l}\text { "Kampong Pelegong Homestay is one of the } \\
\text { products that we sell" } \\
\text { "We package Kampong Pelegong Homestay for } \\
\text { customers who wish to experience staying in the } \\
\text { kampong...we sell quite a few of these packages" }\end{array}$ \\
\hline
\end{tabular}

Several questions were posed to the respondents in an effort to understand their level of interests, power, dependency and stakes relating to the homestay programme. The findings reveal that each of the respondents had different reasons for being interested in KPH Programme development. The officials interviewed are attached to the Ministry of Tourism at the Federal and State level and are both responsible for the promotion of $\mathrm{KPH}$ Programme and the budget allocation for its development. The $\mathrm{KPH}$ Programme is important for them as its development and performance in attracting tourists will give an indication that these respondents have excelled in promoting the program, which is identified by the ministry as one of Malaysia's 
emerging tourism product. At the same time, the KPH Programme depends on these respondents for budget allocation for its development. The respondents want the programme to be successful, while the community of Kampong Pelegong depends on the respondents for financial support. Thus, this group is considered to have power yet they are somewhat dependable on the development of KPH Programme as it is their responsibility to promote the programme (High power, High dependence, and High stakes in Table 2).

The KPH Programme is run by the KPH Association. Members of this association consist of the homestay operators and other residents who are not homestay operators but who are interested in assisting the running of the programme. The programme depends completely on locals for these labour needs and the association committee help manage labour. These individuals are not paid directly for this management duty, but as a token for their commitment, they may stand a chance to be sent to represent the association in activities organized by the Malaysia Homestay Association including promotional activities. The association had even sent several committee members to participate in the State's Tourism Overseas Sales Mission to expose them to the industry.

Interviews with two of these committee members have revealed that they lead the program's planning and operation without any contractual wages. One of the respondents mentioned in the interview that profit from the homestay is divided among the members of the association. The association also retains part of the profit and any contributions from the government in the association account, and the money is used for the homestay future operations and development. The success of the homestay programme will spill over to these particular respondents; the more profitable the program, the bigger the monetary returns these respondents will eventually receive. For the purpose of this study, this group can be considered to have high degree of power in the development of the homestay programme and they are also dependent on the programme (High power, High dependency, and High stake in Table 2).

The third group of respondents consists of nine operators in KPH Programme. They are Kampong Pelegong residents who are certified to offer their homes for the programme visitors to stay. The nine respondents in this group are among Kampong Pelegong residents who are able to fulfil the ministry's requirement for certification. Their extra room in their clean and safe homes and their time are the resources that enable them to be involved in the homestay programme. The respondents in this group are very keen to see the progress of the programme and they want to see more visitors to enter the programme. The respondents also agree, after much probing by the researchers, that the income they received by being hosts in the programme brings significant meanings to their lives. This group of respondents can be considered to have high power level in the homestay programme as it cannot be sold without then. Nevertheless, this group is dependent on the programme for extra income and the stake 
they have in the programme is high; the more successful this programme is, the more chances they will have to benefit economically (High power, High dependency, High stake in Table 2).

The next set of respondents consists of the residents who are neither hosts nor members of KPH Association They have their own reasons for not participating in the programme. One of them is an elderly man who lives with his elderly wife while another is a young mother with five children who does not have any spare rooms to allow her to host any visitors. Another respondent in this group simply "...does not have time to help out in the programme". They indicate that their livelihoods do not depend economically on the progress of the homestay but they are keen to see the success of the programme and they believe that the programme brings benefit to the community in general. This group of respondents are considered to have low power (the programme still goes on without their participation), low dependency on the programme as they do not depend on the programme in their livelihood, but high stake as their daily lives may be effected by the presence of visitors in their community.

Five guests to KPH Programme were interviewed in the study. The study finds that this group depends on the homestay programme to provide them with educating experience and comfortable stay but the homestay programme depends on them more as the programme essentially cannot exist without the guests as their clients. The homestay depends on the guests for their business; the guests do not depend on the homestay for their vacation experience and services as there are other destination alternative they can choose (High power, Low dependency, Low stake in Table 2).

Another two categories of respondents are the organizers that bring groups to $\mathrm{KPH}$ Programme but are not from the travel industry (leaders of two motivational consulting companies that conduct trainings to their clients at KPH Program), and the travel intermediaries that sell KPH Programme to interested travelers. Interviews with these respondents reveal that they are also the program's clients as they bring their participants to stay at the homestay programme. Thus, they are very important to the homestay program, and similar to the homestay guest group in the previous paragraph, they are the reason for the homestay programme thrive. Similarly, they are not dependent on the homestay programme as they can choose to bring their clients elsewhere (High power, Low dependence level, Low stake in Table 2).

Thus, the findings indicate that stakeholders surrounding Kampong Pelegong Homestay programme development differ in terms of their interest, power and dependence level, and their perceived stake from the development. The findings are summarized in Table 2. 
Table 2 Interests, power, dependency and stakes of the stakeholder respondents

\begin{tabular}{|l|l|c|c|c|}
\hline Category & Interests & $\begin{array}{l}\text { Power in } \\
\text { relationship }\end{array}$ & $\begin{array}{l}\text { Dependency } \\
\text { on program }\end{array}$ & Stakes \\
\hline $\begin{array}{l}\text { Government } \\
\text { officials }\end{array}$ & $\begin{array}{l}\text { National } \\
\text { tourism } \\
\text { promotion/ } \\
\text { developmental } \\
\text { concerns }\end{array}$ & High & High \\
\hline $\begin{array}{l}\text { KPH } \\
\text { Programme } \\
\text { committee } \\
\text { members }\end{array}$ & $\begin{array}{l}\text { Community } \\
\text { interest/ } \\
\text { economic } \\
\text { interest }\end{array}$ & High & High & High \\
\hline $\begin{array}{l}\text { KPH } \\
\text { Programme } \\
\text { hosts/ } \\
\text { certified } \\
\text { operators }\end{array}$ & $\begin{array}{l}\text { Economic } \\
\text { interest }\end{array}$ & High & High & High \\
\hline $\begin{array}{l}\text { Kampung } \\
\text { Pelegong } \\
\text { residents }\end{array}$ & $\begin{array}{l}\text { Community } \\
\text { interest }\end{array}$ & Low & Low & High \\
\hline $\begin{array}{l}\text { KPH } \\
\text { Programme } \\
\text { guests }\end{array}$ & $\begin{array}{l}\text { Recreational } \\
\text { interest }\end{array}$ & High & Low & Low \\
\hline Organizers & $\begin{array}{l}\text { Economic } \\
\text { interest }\end{array}$ & High & Low & Low \\
\hline $\begin{array}{l}\text { Tour } \\
\text { openomic }\end{array}$ & High & Low & Low \\
\hline
\end{tabular}

The respondents were also asked for their opinions and concerns regarding the development of Kampong Pelegong Homestay Programme and the responses were analyzed to explore if their opinions differ according to their power and perceived stake from the development.

\section{Government officials}

An interview with a government officer attached with Tourism Malaysia revealed that homestays are becoming an important tourism product for Malaysia. Promoting homestay is one of Malaysia's marketing strategies in product differentiation. "The homestay programme in the country is part of the evolution of our growing tourism industry, taking advantage of the natural attractions, cultures and customs and unspoilt beauty of the surrounding. Rural tourism is a way to respond to changing 
needs of tourists to lure them to Malaysia," he said. Another government official respondent even claimed that Kampung Pelegong Homestay Programme has created wealth among the residents. "A few of them are able to earn more than a thousand ringgits per month from the homestay," he asserted seriously.

\section{KPH Programme operators and committee members}

In general, hosts and members of KPH Programme voiced their satisfaction on how the programme has improved the village and how the outcomes from the programme are more positive than negative. The programme is perceived to help instil patriotism, confidence, and leadership among the youth. Although the hosts and members appreciate the income contribution from their involvement in the program, they feel that income is a secondary outcome. They believe that the instillation of the feeling of love towards the village and their neighbours, and the sense of belongingness precedes the monetary gain.

The interviews with the programme operators reveal that they are glad that the homestay allows them to be involved in the country's tourism development, as explained by one of the host:

"I am excited and thankful because the government has introduced homestay...introduced us to homestay...the government really supports homestay all over Malaysia. Now we know the importance of tourists in developing the country...we know more about the tourists...because we receive tourists from all over the world. This homestay is easy to do, as long as we want to...the government also provides training."

Nevertheless, the interviews revealed perceptions among the hosts and participants of the existence of middlemen that reap the profits in the process of getting visitors to the programme. A host explained that the motivational consulting companies that bring their training groups take advantage of the homestay programme for monetary gain. Another host suggested that the price charged to the visitors should be increased. This finding seems to contradict the earlier indication that income was not the reason they participated in the homestay program; there is a hint here that they indeed look forward to the income from the programme.

\section{Kampung Pelegong residents}

Interviews with the villagers who do not take part in the programme indicate that they are not against the programme and they do not antagonize the visitors. None of them has ever encountered any problem or felt unnecessary burden by having visitors to their community. In fact, they suggested that the government and the association need to intensify the promotional activities in order to attract more tourists to come and stay in the programme. However, they do not feel that they are obligated to put much effort to support the programme. As an example, one of them claimed that he was not 
too keen to give up part of his land when asked to do so in an effort to widen the village roads. One of them also mentioned the need to remind the tourists about the local culture and religion.

\section{KPH Programme guests}

Visitors to KPH Programme that were interviewed mentioned that the experience from their stay in the homestay programme was entertaining and enriching. Not only do they understand the villagers' way of life and the local culture better, but they were overwhelmed with the warm and sincere hospitality given by the hosts and the organizers. One visitor even mentioned that this type of tourism product "...has the potential to promote world peace”. Nevertheless, there are several issues voiced by the guests. The first was about cleanliness especially when it relates to food preparation and toilets. It is accepted by all the respondents in this category that the toilet in the homes that they were staying in are "not very dirty" but they could be cleaner and smell better. One of the respondent explained, "...the cleanliness could be improved, I mean, the visitors are here to experience the uniqueness, but they also want to be rest assured that they will not conceive any illness due to unhygienic environment."

The second issue relates to the communication facilities in the homestay programme. Three of the respondents mentioned that they could not make calls using their mobile phones because the absence of coverage. There are also no public phones in the village, thus adding their difficulties to keep in touch with their families. A guest respondent urges that guests should not be "cocooned" in the programme because there are times when they really need to make calls. Another respondent feels that the programme can be more attractive if an internet centre is provided.

\section{Organisers}

Due to its location and facilities, the organizers of the motivational consultant programs are keen on the development of KPH Programme because it matches their requirement for a place to run their training programs. These organizers are important clients for the program; their satisfaction with programme would most probably assure sustained profits to the programme.

When asked about their concerns and opinions about the development of KPH Programme as a cultural rural tourism product, the respondents from this category mentioned the improvement of facilities such as upgrading the multipurpose hall and provision of a better way to transport the participants from one place to another. It is apparent that the KPH Programme depends on these organizers to sustain its business. On the other hand, these organizers have little stake in KPH Program, especially with the increasing number of new rural community-based homestay programs throughout Malaysia. These new homestay programs create more choices and alternatives for the organizers. 


\section{Tour operators}

Since the product has not been fully developed, tour operators are not so keen in promoting and selling homestay packages. An operator that was interviewed explained that this is because "... they don't see much commission to be earned from the product (homestay programs)." He added, "There are a lot of improvements need to be done to make homestay a big thing. It must be well developed and it must offer reliable services. If they increase their offerings, then they could charge higher prices, and we can get better commissions." He also believes that Homestay Kampong Pelegong is becoming a 'cheap' training centre for training consultant companies who mostly charge big fee to their clients. In his opinion, adding and upgrading the facilities will help attract more tourists, “... and the facilities must have international standards and quality."

\section{Conclusion}

This study began by an understanding that planners must take into account interests and concerns of stakeholders in the planning, development, and management processes. Guided by stakeholder, social exchange and power theories, a case study approach was undertaken to examine these interests and concerns based on the stakes and power of different stakeholders in the development of Kampung Pelegong as a homestay programme.

Based on the findings, the study conclude that the stakeholders' interest in the development of the homestay may be explained by any or by the combination of the three components: their power, or their lack of power, to affect programme (based on the resources that may be of use to the program), their dependency on the programme (how important the programme is to them), and the stakes (what is in it for them) they have on the development. Stakeholders have interests in the programme development when they are affected by the programme (their stakes in the development are high) or when they can affect the programme (their stakes in the development are low but their power in the relationship is high.)

A stakeholder, with the exception for the residents, will have 'something in it' in the programme when they have the power or when they are dependent on the program, or both. Those with high stakes (who are also dependent on the program) will be more willing to be involved in the development while those with low stakes or less dependent on the programme are less willing to be involved.

The residents appear to be a unique stakeholder category as their stakes in the programme is high yet they are not dependent on the programme. Their stakes in the homestay programme is mainly non-economic in nature. Their stakes may be explained by the feeling of care or concern that they expect to get from those responsible in the programme development in making certain that the programme will not jeopardize their quality of lives. 
Findings from the study bear practical and theoretical implications. Practically, rural tourism planners in Malaysia are now able to understand why some group are interested or not interested in rural tourism development in their area. Interests may then be increased by empowering these groups or by giving them some stakes in the development. The different concerns of different stakeholders' may be explained by the differences in their interests, which is explained by their power level, their dependency on the program, and the stakes they have on the development. Although further research is understandably needed to explore the abovementioned proposition, it can be suggested that stakeholder, social exchange, and power theories are useful in understanding concerns and issues of any type of tourism development.

\section{References}

1. Axelrod, R. (1984) The Evolution of Cooperation. New York: Basic Books.

2. Ayers, J. S., H. R. Potter (1989) Attitudes toward community change: A comparison between rural leaders and residents. Journal of the Community Development Society, 20(1), pp. 1-18

3. Black, A. (1996) Negotiating the tourists gaze: The example of Malta. In Boissevain, J. (ed.) (1996) Coping with Tourists: European Reactions to Mass Tourism. Oxford: Berghahn Books, pp. 112-142

4. Bramwell, B., A. Sharman (1999) Collaboration in local tourism policymaking. Annals of Tourism Research, 26(2), pp. 392-415

5. Burton, D. K, C. P. Dunn (1996) Feminist ethics as moral grounding for stakeholder theory. Business Ethics Quarterly, 6(2), pp. 2-15.

6. Easterling, D. (2005) Residents and tourism: What is really at stake? Journal of Travel and Tourism Marketing, 18(4), pp. 49-65

7. Fatimah Basiron (2005) Personal Communication

8. Freeman, R. E. (1984) Strategic Management: A Stakeholder Approach. Boston: Pitman

9. Gall, M.D, W. R. Borg, J. P. Gall (1996) Educational Research: An Introduction. $6^{\text {th }}$ ed., White Plains, NY: Longman Publishers

10. Goudy, W. J. (1977) Evaluations of local attributes and community satisfaction in small towns. Rural Sociology, 42(3), pp. 371-382

11. Hall, C. M., A. A. Lew, (1998) Sustainable Tourism: A Geographical Perspective. New York: Longman

12. Haralambopoulos, N., A. Pizam (1996) Perceived impacts on tourism: The case of Samos. Annals of Tourism Research, 23(3), pp. 503-526

13. Healy, P. (1998) Collaborative planning in a stakeholder society. Town Planning Review, 69(1), pp. 1-21 
14. Jamal, T. B., D. Getz (1997) 'Visioning' for sustainable tourism development: community-based collaborations. In P. E. Murphy (ed.) (1997) Quality Management in Urban Tourism. Chichester: Wiley, pp. 199-220

15. Kayat, K. (2000) Power through Tourism: A Blessing on Mahsuri's Eighth Generation in Langkawi? Unpublished dissertation. East Lansing, Michigan: Michigan State University

16. Kayat, K. (2007) Customer Orientation among Rural Home Stay Operators in Malaysia. ASEAN Journal on Hospitality and Tourism, 6(2), pp. 65-78

17. Lankford, S. V. (1994) Attitudes and perceptions toward tourism and rural regional development. Journal of Travel Research, 32(4), pp. 35-43

18. Levine, S., P. White (1961) Exchange as a conceptual framework for the study of interorganizational relationships. Administrative Science Quarterly, 5(4), pp. 583-601

19. Lewis, J. (1998) A rural tourism development model. Tourism Analysis, 2(2), pp. 91-105

20. MacDonald, R., L. Jolliffe (2003) Cultural rural tourism: evidence from Canada. Annals of Tourism Research, 30(9), pp. 307-322

21. McGehee, N. G., K. L. Andereck (2004) Factors predicting rural residents' support of tourism. Journal of Travel Research, 43(2), pp. 131-140

22. Milman, A., A. Pizam (1988) Social impacts of tourism on Central Florida. Annals of Tourism Research, 15(2), pp. 191-204

23. Ministry of Culture, Arts and Tourism (2001) Rural Tourism Plan. Kuala Lumpur: Ministry of Culture, Arts and Tourism

24. Murphy, P. E. (1981) Community attitudes to tourism: a comparative analysis. Tourism Management, 3(2), pp. 189-195

25. Pearce, P. L., A. M. Morrison, J. L. Rutledge (1998) Tourism: Bridges Across Continents. Australia: Irwin-McGraw-Hill

26. Pizam, A., J. Pokela, (1985) The perceived impacts of casino gambling on a community. Annals of Tourism Research, 12(issue 2), pp. 147-165

27. Ritchie, J. R. B. (1993) Crafting a destination vision. Putting the concept of resident-responsive tourism into practice. Tourism Management, 14(5), pp. 379-389

28. Ritchie, J., L. Spencer (1995) Qualitative data analysis for applied policy research. In A. Bryman and R. Burgess (eds.) Analyzing Qualitative Data, London: Routledge, pp. 85-94

29. Robson, J., I. Robson (1996) From shareholders to stakeholders: critical issues from tourism marketers. Tourism Management, 17(7), pp. 533-540

30. Ryan, C. (1995) Researching Tourist Satisfaction: Issues, Concepts, Problems. London: Routledge 
31. Savage, G., T. Nix, C. Whitehead, J. Blair (1991) Strategies for assessing and managing organizational stakeholders. Academy of Management Executive, 5(2), pp. $51-75$

32. Sekaran, U. (1992) Research Methods for Business: A Skill Building Approach ( $2^{\text {nd }}$ ed.), New York: John Wiley and Sons

33. Sittamparam, R. (2008) More homestay operators wanted. The New Straits Times May 4, p. 24

34. Tyrrell, T, I. A. Spaulding (1984) A survey of attitudes toward tourism growth in Rhode Island. Hospitality Education and Research Journal, 8(2), pp. 22-33

35. United Nations Development Programme (2003) Rural Tourism Master Plan for Malaysia. Kuala Lumpur: Ministry of Tourism, Malaysia.

36. Yuksel, F., B. Bramwell, A. Yuksel (1999) Stakeholder interviews and tourism planning at Pamukkale, Turkey. Tourism Management 20(3), pp. 351-360

RECEIVED: 17.02 .2008

ACCEPTED: 14.08 .2008 